University of Nebraska - Lincoln

DigitalCommons@University of Nebraska - Lincoln

Faculty Publications from the Harold W. Manter Laboratory of Parasitology

4-1947

Suggestions for the Handling of Certain Mammals

Robert L. Rausch

Michigan State College, rausch@u.washington.edu

Follow this and additional works at: https://digitalcommons.unl.edu/parasitologyfacpubs

Part of the Parasitology Commons

Rausch, Robert L., "Suggestions for the Handling of Certain Mammals" (1947). Faculty Publications from the Harold W. Manter Laboratory of Parasitology. 575.

https://digitalcommons.unl.edu/parasitologyfacpubs/575

This Article is brought to you for free and open access by the Parasitology, Harold W. Manter Laboratory of at DigitalCommons@University of Nebraska - Lincoln. It has been accepted for inclusion in Faculty Publications from the Harold W. Manter Laboratory of Parasitology by an authorized administrator of DigitalCommons@University of Nebraska - Lincoln. 


\section{SUGGESTIONS FOR THE HANDLING OF CERTAIN MAMMALS}

For experimental work, it is often desirable to handle the smaller wild mammals more freely than usual methods allow. Howell (Jour. Mamm. 18(4): 513, 1937) suggests the feeding of pentobarbital sodium in milk or other food. While this may be satisfactory for animals accustomed to captivity, it can hardly be used for those newly captured.

In trapping a number of mammals for infection experiments, box traps being used for this purpose, the captured animals were driven from the trap into a mesh sack. While thus restrained, pentobarbital sodium solution was injected intraperitoneally, and within a short time the animals would become either unconscious or sufficiently narcotized to allow the desired amount of handling. The recommended dosage of $1 \mathrm{cc}$. (containing 1 grain of pentobarbital sodium) per pound of body weight was used. The weight could only be estimated in the field, but in no case was there any undesirable result; a few animals remained unconscious for a longer period of time than was necessary.

No attempt was made to make the injec- tions aseptically. The animals were kept for a considerable time after their capture, and none showed any evidence of introduction of infection by the needle, either while alive or when autopsied. This method was used on raccoons, woodchucks, fox squirrels, and cottontails.

In order to avoid the odor another method was used for skunks. Avoiding unnecessary disturbance, the door of the trap was opened, and the skunk induced to enter a cardboard carton through a small opening in the side of the latter. The opening was then closed and either chloroform or ether poured through a small opening in the top. As soon as it was evident from lack of movement that the animal was unconscious, it was removed. The several skunks handled by us did not eject any scent under these circumstances.

Both methods were adequate for our work, and it is assumed that they are equally applicable for other purposes.-RoBert RA USCH, Department of Bacteriology and Public Health, Michigan State College, East Lansing, Michigan. 